\title{
Investigation of Tenascin Expression in Endometriosis
}

\author{
Zehra Sema Ozkan, ${ }^{1}$ Hasan Cilgin, ${ }^{1}$ Remzi Atilgan, ${ }^{1}$ Mehmet Simsek, ${ }^{1}$ \\ Bengu Cobanoglu, ${ }^{2}$ Necip Ilhan, ${ }^{3}$ and Ekrem Sapmaz ${ }^{1}$ \\ ${ }^{1}$ Department of Obstetrics and Gynecology, School of Medicine, Firat University, 23119 Elazig, Turkey \\ ${ }^{2}$ Department of Pathology, School of Medicine, Firat University, 23119 Elazig, Turkey \\ ${ }^{3}$ Department of Biochemistry, School of Medicine, Firat University, 23119 Elazig, Turkey
}

Correspondence should be addressed to Zehra Sema Ozkan, zehrasema@yahoo.com

Received 17 November 2012; Accepted 9 December 2012

Academic Editors: A. Gocht, A.-J. Kruse, and A. Stringer

Copyright ( 2012 Zehra Sema Ozkan et al. This is an open access article distributed under the Creative Commons Attribution License, which permits unrestricted use, distribution, and reproduction in any medium, provided the original work is properly cited.

\begin{abstract}
Objective. To evaluate the serum and tissue levels and local expression pattern of tenascin, a high molecular weight extracellular matrix protein, in eutopic and ectopic endometrium from patients with and without endometriosis and to compare the proliferative and secretory phase differences. Materials and Methods. Thirty women with endometriosis and fifteen women without endometriosis undergoing surgery for benign indications were included in the study. Serum and tissue levels and proliferative and secretory phase expression patterns of tenascin in the ectopic and eutopic endometrium were analyzed with immunohistochemistry and immunoassays. The results were compared with Mann-Whitney $U$ test. $P$ values $<0.05$ were considered as statistically significant. Results. Tenascin expression was detected in both of eutopic and ectopic endometrium of women with and without endometriosis. In immunohistochemical staining, intense staining of tenascin was observed in glandular cells of eutopic and ectopic endometrial tissue samples of both groups during secretory phase $(P<0.01)$. Eutopic and ectopic tissue levels of tenascin were higher than serum tenascin levels only secretory phase $(P=0.02)$. There was no significant difference between groups for tissue and serum levels of tenascin during cycle phases. Conclusion. Tenascin expression showed cyclic change on eutopic and ectopic endometrium.
\end{abstract}

\section{Introduction}

Endometriosis is characterized by the presence of endometrial stromal and glandular cells outside the uterine cavity, mainly in the pelvis [1]. The exact etiology and pathophysiology of the disease is still not clear. The widely accepted theory is retrograde menstruation and implantation of endometrial cells on peritoneal surface [2-4]. Endometriotic cells are capable of attaching to the peritoneal mesothelium, break the peritoneal lining, and destroy extracellular matrix (ECM), thereby invading surrounding tissue [5]. ECM is involved in the regulation of these cellular events, and ECM invasion may be on the critical corner of endometriotic development.

Tenascin is a high molecular weight ECM protein and plays a critical role in tissue regeneration, hyperplastic, and neoplastic processes [6]. Tenascin may have function in angiogenesis by the effect of migration of vascular endothelial cells [7]. Tenascin expression in endometrium is changing under the influence of ovarian steroids during menstruel cycle. The function of endometrial tenascin is not well known but, it is thought that tenascin plays role in endometrial regeneration and endometriotic implantation via cellular adhesion [8]. In this study we aimed to investigate the expression pattern of tenascin in eutopic and ectopic endometrial tissues.

\section{Materials and Methods}

2.1. Tissue and Blood Samples. Tissue samples were collected in accordance with the requirements of the Firat University Hospital Ethical Committee between November 2008 and September 2009. Eutopic and ectopic endometrial samples were obtained from 45 women aged 18-40 years, body mass index ranged from 18.5 to $24.9 \mathrm{~kg} / \mathrm{m}^{2}$ undergoing 
laparoscopy for benign indications, who had a regular 2633 day menstrual cycle and who had received no hormonal medication in the preceding 3 months. Forty-five women classified into two groups; Group I: women who did not have pelvic pathology that was confirmed by ultrasonography and laparoscopy $(n=15)$, Group II: women with endometriosis (ASRM-stage II and III; $n=30$ ). Samples of endometriotic implants and endometriomas were obtained at laparoscopy, and the disease was confirmed by histological examination of the biopsies. Eutopic endometrium was obtained from endometrial biopsies during surgery. Sections of endometrium and endometriosis taken from these samples were examined histologically and assessed for proliferative or secretory endometrial morphological features, using the criteria of Noyes et al. [9]. Forty-five samples of endometrium (22 proliferative, 23 secretory) from 15 women with a normal pelvis and 30 women with endometriosis were used for immunohistochemical and enzyme immunoassay analysis. Samples of endometriosis (16 from women in the proliferative stage and 14 from women in the secretory stage of the menstrual cycle) were obtained from 15 ovarian endometriomas and 15 peritoneal implants. Semiquantitative estimation of tenascin staining was evaluated as an index of staining intensity and distribution. Also $5 \mathrm{~mL}$ peripheric venous blood samples were collected for enzyme immunoassay. Written informed consent was obtained from each patient using consent forms.

2.2. Enzyme-Linked Immunosorbent Assay (ELISA). Peripheric venous $5 \mathrm{~mL}$ blood samples were collected after onenight fasting. After centrifugation of blood samples at $4000 \mathrm{rpm}$ at room temperature for 10 minutes, $20-30 \mu \mathrm{L}$ aprotinin/mL (400 kallikrein inactivator units, KIU) and $1 / 10$ volume $1 \mathrm{~N} \mathrm{HCl}$ were supplemented into serum samples. Samples were then stored at $-20^{\circ} \mathrm{C}$ until analysis. Eutopic and ectopic endometrial tissue samples were divided into two parts: formaldehyde embedded-tissue for immunohistochemical analysis and the remaining tissue for ELISA. Approximately $15 \mathrm{mg}$ tissue samples were boiled at $100^{\circ} \mathrm{C}$ for 5 minutes, then were squashed on iron mold and were homogenised in phosphate-buffered saline (PBS) $(5 \%, w / v)$. The homogenised samples were centrifugated at $4000 \mathrm{rpm}$ at room temperature for 10 minutes. For accurate quantification of tenascin levels in tissue samples, 20-30 $\mu \mathrm{L}$ aprotinin/mL (400 kallikrein inactivator units, KIU), and $1 / 10$ volume $1 \mathrm{~N} \mathrm{HCl}$ were supplemented into tissue samples. Samples were then stored at $-20^{\circ} \mathrm{C}$ until analysis. Tenascin levels of extracted plasma and tissue samples were assayed with Human Tenascin kit (Active; Phoneix Pharmaceuticals, Germany).

2.3. Immunohistochemistry. Paraffin-embedded tissue samples were cut into $5 \mu \mathrm{m}$ sections and mounted on Poly-LLysine slides (Lab Vision Corporation, USA). Slides were deparaffinized in xylene and rehydrated in a graded series of alcohol. Endogenous peroxidase activity was quenched by incubation in $3 \% \mathrm{H}_{2} \mathrm{O}_{2}$ for 10 minutes and was followed by a rinse with PBS. For antigen retrieval, slides were placed in $10 \mathrm{mmol} / \mathrm{L}$ citrate buffer $(\mathrm{pH} 6.0)$ and were microwaved twice for 5 minutes. Nonspecific binding of the primary antibody was prevented by incubation in Ultra $\mathrm{V}$ Bloc. Sections were then incubated with rabbit polyclonal tenascin antibody (ab59469, Abcam Inc.) as primary antibody for 30 minutes at $38^{\circ} \mathrm{C}$. Thereafter, sections were washed with PBS and incubated in biotinylated goat antiserum (Lab Vision Corporation) for 10 minutes at $38^{\circ} \mathrm{C}$. After rinse in PBS again, the slides were incubated in streptavidinbiotin-peroxidase (SBP) for 10 minutes. The slides were washed with PBS twice for 5 minutes, and then aminoethyl-carbazole (AEC) was used as chromogene for 10 minutes. Mayer Hematoxylin was used for counter staining. The intensity for tenascin immunoreactivity in eutopic and ectopic endometrial tissues were semiquantitatively evaluated as positively stained stromal and glandular cells using the following intensity categories: 0 (no staining), 1+ (weak but detectable staining), 2++ (moderate or distinct staining), and $3+++$ (intense staining). In each slide, five different areas were evaluated under a microscope with $\times 60$ objective magnification for each intensity within these areas were determined by two investigators blinded to the type and source of the tissues. The average intensity of two was used.

\section{Statistical Analysis}

Power calculation was performed based on previous studies that involved semiquantification of tenascin expression by immunohistochemistry. A sample size of 15 in each group has $80 \%$ power to detect a difference between means of 22.07 with a significance level (alpha) of .05 . The statistical power analysis was performed using $\mathrm{G}$ power 3 programme. Statistical analysis was performed by Statistical Package for Social Sciences (SPSS) version 12.0 (Inc., Chicago, IL, USA). Results were expressed as mean and standard deviation. Differences in two groups for continous variables were analyzed using Student's $t$-test. Differences in two groups for ordinal variables were analyzed using Mann-Whitney $U$ test. $P$ values $<0.05$ were considered as statistically significant.

\section{Results}

The age, BMI, and waist/hip ratio of patients were as follows: $30.2 \pm 5.5$ years, $22.1 \pm 1.8 \mathrm{~kg} / \mathrm{m}^{2}$, and $0.72 \pm 0.06$ and there was no difference between groups in these parameters $(P>$ 0.05 ). The serum and tissue levels of tenascin in both of the groups were presented in Figure 1 and Table 1. There was no significant difference between serum and tissue levels of tenascin in both of the groups $(P>0.05)$. Serum tenascin levels did not show cyclic change, but both of the eutopic and ectopic endometrial tissue tenascin levels increased during secretory phase and decreased in proliferative phase. Endometrial levels of tenascin were higher than serum levels of tenascin only secretory phase $(P=0.03)$. Eutopic and ectopic endometrial tissue levels of tenascin did not differ between groups $(P=0.43)$. Immunohistochemical staining of tenascin in eutopic endometrium of both groups were dominant in secretory phase $(P<0.01)$. But comparison of 


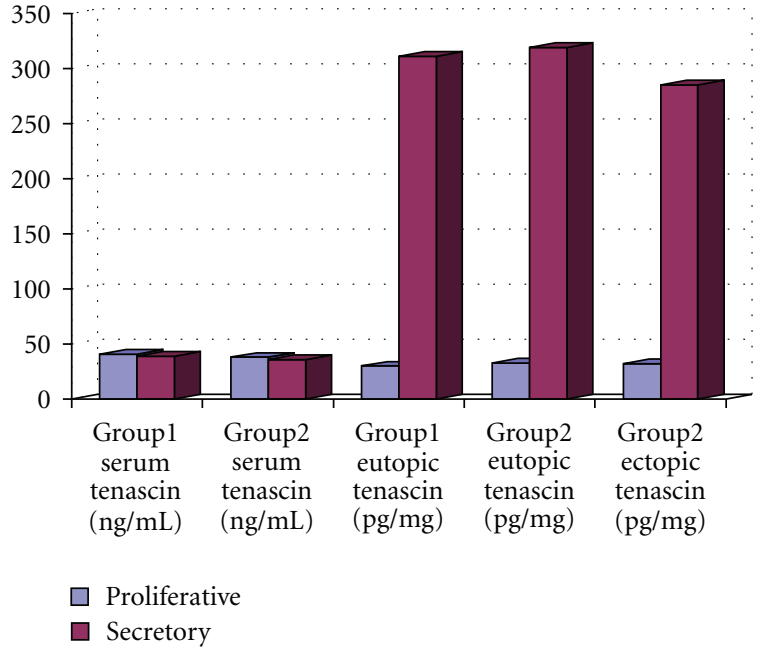

Figure 1: Serum and tissue levels of tenascin in women with and without endometriosis.

TABle 1: Serum and tissue levels of tenascin.

\begin{tabular}{|c|c|c|c|}
\hline & $\begin{array}{l}\text { Group 1 } \\
(n=15)\end{array}$ & $\begin{array}{l}\text { Group 2 } \\
(n=30)\end{array}$ & $P$ value \\
\hline \multicolumn{4}{|l|}{ Serum tenascin $(\mathrm{ng} / \mathrm{mL})$} \\
\hline (i) Proliferative phase & $41 \pm 7$ & $38 \pm 8.5$ & 0.73 \\
\hline (ii) Secretory phase & $39 \pm 9$ & $36 \pm 9$ & 0.95 \\
\hline \multicolumn{4}{|c|}{$\begin{array}{l}\text { Eutopic endometrial tenascin } \\
(\mathrm{pg} / \mathrm{mg})\end{array}$} \\
\hline (i) Proliferative phase & $30 \pm 9$ & $33 \pm 14$ & 0.93 \\
\hline (ii) Secretory phase & $319 \pm 109$ & $311 \pm 127$ & 0.71 \\
\hline \multicolumn{4}{|c|}{$\begin{array}{l}\text { Ectopic endometrial tenascin } \\
(\mathrm{pg} / \mathrm{mg})\end{array}$} \\
\hline (i) Proliferative phase & - & $32 \pm 11$ & - \\
\hline (ii) Secretory phase & - & $285 \pm 100$ & 一 \\
\hline
\end{tabular}

Note: The results are presented as mean $\pm \mathrm{SD}$.

eutopic and ectopic endometrial tissue tenascin staining did not show a significant difference between groups $(P=0.71)$.

In immunohistochemical staining, intense staining of tenascin was observed in glandular cells of eutopic endometrial tissue samples of both groups during secretory phase (Figure 2). Also endometriotic tissue samples showed intense tenascin staining in glandular cells during secretory phase $(P<0.01)$. Stromal cells of endometriotic and eutopic tissues showed weak staining for tenascin, so cyclic variation could not be analyzed in their expression levels. Independent of menstruel cycle phase, staining intensity of tenascin was moderate in eutopic and ectopic endometrial tissues.

4.1. Comments. The present study evaluated the serum and tissue levels of tenascin in eutopic and ectopic endometria. Immunohistochemical and immunoassay results pointed out increased tenascin expression during secretory phase in glandular cells of eutopic and ectopic endometrium. However, the changes in stromal cells were less dynamic than those in glandular cells of both eutopic and ectopic endometrium.
Increased tissue levels of tenascin during secretory phase may indicate a paracrine function on endometrium and the influence of ovarian steroids on tenascin expression. The limitations of our study were the small study population and immunohistochemical analysis of tenascin, could be supported with the genetic analysis of tenascin expression.

Invasion, ectopic implantation, and recurrence are the pseudomalignant characteristics of endometriosis. New vessel formation, alteration of cellular immunity response, and apoptosis suppression are the integral mechanisms in the pathogenesis of endometriosis [10]. The occurrence of endometriosis is most common in women of reproductive age and rare after menopause, and estrogen is the inducer of disease [11]. The proliferative effect of estrogen on the endometrium is managed by substances such as growth factors and the ECM, and it is thought that epithelialmesenchymal interactions play a critical role in this process [12]. It has been reported that estrogen has mitogenic effect on endometrial cells [13] and a paracrine interaction between stromal and epithelial cells might play an important role in estrogen-induced endometrial cell proliferation [14]. Therefore, it is likely that the growth regulation of endometriotic cells is controlled by a complex interaction of ECM proteins and sex steroids.

The function of endometrial tenascin is not well known but, it is thought that tenascin affects endometrial regeneration and endometriotic implantation via cellular adhesion [8]. Harrington et al. demonstrated that the distribution of tenascin is widespread in the stroma of endometriotic tissue and expressed at higher levels in proliferative than in secretory endometrium. Tan et al. reported that ectopic endometrial stromal cells significantly upregulated tenascin protein expression levels to a greater extent than the cells from the proliferative phase of normal endometrium with estrogen treatment and tenascin expression was inhibited by cotreatment with estrogen receptor antagonist [15]. But in our study, stromal expression levels were very weak in either eutopic or ectopic endometrial tissue and secretory endometrium showed higher expression levels than proliferative endometrium. And there were no difference between expression level of eutopic and ectopic endometrial glandular and stromal cells. The difference of our results from these two studies may arise from the technical dissimilarity of immunohistochemical analysis.

Nishiura et al. reported that tenascin-C upregulated the expression of MMP-3 in mouse endometrial stromal cells during early pregnancy [16]. Slater et al. observed 2 fold increment in the label of tenascin expression during attachment and implantation period of rat blastocyst [17]. Another investigator reported that tenascin-C expression in the preimplantation period of murine endometrium was under the control of progesterone, possibly by the paracrine and autocrine intervention of IL-1 alpha secreted by epithelial cells and $\mathrm{PGE}_{2}$ and $\mathrm{PGF}_{2}$ alpha secreted by stromal cells [18]. Taguchi et al. studied tenascin expression on endometrial tissue obtained from women with regular menstruation undergoing hysterectomy due to benign uterine disease. They established intense deposition of tenascin fibrils in the ECM of the stroma during proliferative phase and markedly 

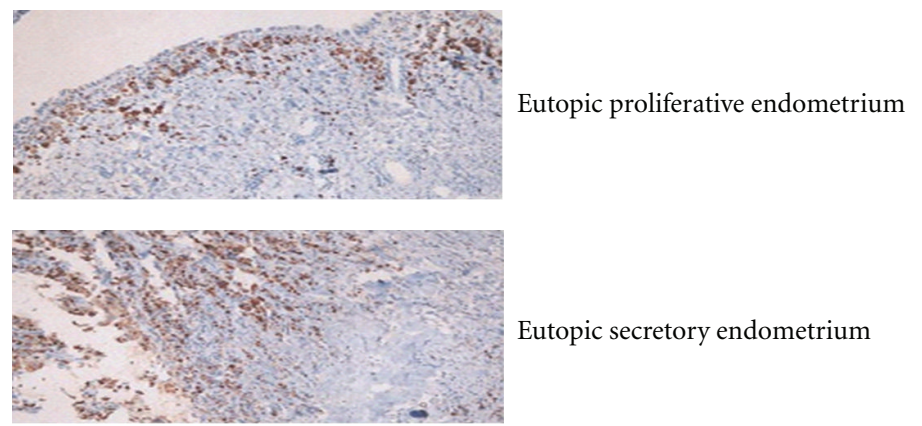

Eutopic secretory endometrium

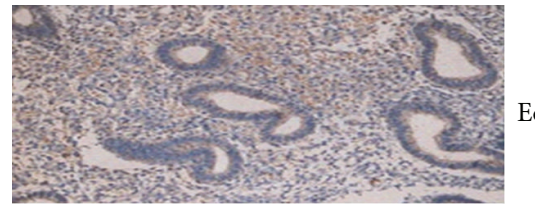

Ectopic proliferative endometrium

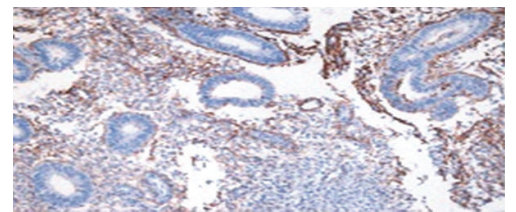

Ectopic secretory endometrium

Tenascin

FIGURE 2: Immunostaining of tenascin in eutopic and ectopic endometria. In eutopic and ectopic endometrial glands tenascin was expressed diffusely in the secretory phase and downregulated in the proliferative phase. Stromal staining intensity of tenascin was very low in both of the eutopic and ectopic endometria $(\times 200)$.

reduction of tenascin expression during secretory phase [19]. Sedele et al. investigated positive tenascin staining in the vascular and glandular basal membranes, stromal cells, and epithelial cells of proliferative, hyperplastic, and neoplastic endometrium [20].

It is thought that epithelial-mesenchymal interactions with the influence of sex steroids play a critical role on endometriosis [11-14]. It is likely that the growth regulation of endometriotic cells is controlled by a complex interaction of ECM proteins and paracrine factors. Similar expression pattern of tenascin in eutopic and ectopic endometrium may indicate that endometriotic lesions share some of the characteristics of the cellular processes involved in the regeneration of endometrium. Presence of tenascin in the ectopic endometrium may point to induction of tenascin by the ectopic epithelium via a factor or factors prevalent in the peritoneal environment of women susceptible to the disease. Tenascin may play a spatiotemporal role for the invasion of peritoneal surfaces by transient expression on ectopic endometrium where ECM degradation is taking place. Thus, it is difficult to explain the proliferative potential of endometriotic epithelia only in terms of the quality or quantity of tenascin.

In conclusion, further studies are needed to investigate the possible effects of tenascin on formation of endometriotic lesions via their paracrine effects on ECM invasion.

\section{Acknowledgment}

The authors thank the doctors of Firat University Hospital, Department of Gynecology for their provided help during their study. This study was supported by Firat University Scientific Research Foundation.

\section{References}

[1] T. Lapp, "ACOG issues recommendations for the management of endometriosis," American Family Physician, vol. 62, no. 6, pp. 1431-1434, 2000.

[2] L. C. Giudice and L. C. Kao, "Endometriosis," Lancet, vol. 364, no. 9447, pp. 1789-1799, 2004.

[3] J. Halme, M. G. Hammond, J. F. Hulka, S. G. Raj, and L. M. Talbert, "Retrograde menstruation in healthy women and in patients with endometriosis," Obstetrics and Gynecology, vol. 64, no. 2, pp. 151-154, 1984.

[4] R. F. P. M. Kruitwagen, L. G. Poels, W. N. P. Willemsen, I. J. Y. de Ronde, P. H. K. Jap, and R. Rolland, "Endometrial epithelial cells in peritoneal fluid during the early follicular phase," Fertility and Sterility, vol. 55, no. 2, pp. 297-303, 1991.

[5] G. Hudelist, J. Keckstein, K. Czerwenka et al., "Estrogen receptor $\beta$ and matrix metalloproteinase 1 are coexpressed in uterine endometrium and endometriotic lesions of patients with endometriosis," Fertility and Sterility, vol. 84, no. 2, pp. 1249-1256, 2005.

[6] G. K. Koukoulis, V. E. Gould, A. Bhattacharyya, J. E. Gould, A. A. Howeedy, and I. Virtanen, "Tenascin in normal, reactive, hyperplastic, and neoplastic tissues: biologic and pathologic implications," Human Pathology, vol. 22, no. 7, pp. 636-643, 1991.

[7] D. Ribatti, G. Loverro, A. Vacca, P. Greco, L. Roncali, and L. Selvaggi, "Expression of tenascin is related to angiogenesis in pre-eclampsia," European Journal of Clinical Investigation, vol. 28, no. 5, pp. 373-378, 1998. 
[8] D. J. Harrington, B. A. Lessey, V. Rai et al., "Tenascin is differentially expressed in endometrium and endometriosis," Journal of Pathology, vol. 187, no. 2, pp. 242-248, 1999.

[9] R. W. Noyes, A. T. Hertig, and J. Rock, "Dating the endometrial biopsy," Fertility and Sterility, vol. 1, pp. 3-25, 1950.

[10] D. P. Braun, J. Ding, F. Shaheen, J. C. Willey, N. Rana, and W. P. Dmowski, "Quantitative expression of apoptosisregulating genes in endometrium from women with and without endometriosis," Fertility and Sterility, vol. 87, no. 2, pp. 263-268, 2007.

[11] J. Kitawaki, N. Kado, H. Ishihara, H. Koshiba, Y. Kitaoka, and H. Honjo, "Endometriosis: the pathophysiology as an estrogen-dependent disease," Journal of Steroid Biochemistry and Molecular Biology, vol. 83, no. 1-5, pp. 149-155, 2002.

[12] Y. M. Huet-Hudson, C. Chakraborty, S. K. De, Y. Suzuki, G. K. Andrews, and S. K. Dey, "Estrogen regulates the synthesis of epidermal growth factor in mouse uterine epithelial cells," Molecular Endocrinology, vol. 4, no. 3, pp. 510-523, 1990.

[13] V. Casimiri, N. C. Rath, H. Parvez, and A. Psychoyos, "Effect of sex steroids on rat endometrial epithelium and stroma cultured separately," Journal of Steroid Biochemistry, vol. 12, pp. 293-298, 1980.

[14] G. R. Cunha, L. W. Chung, J. M. Shannon, O. Taguchi, and H. Fujii, "Hormoneinduced morphogenesis and growth: role of mesenchymal-epithelial interactions," Recent Progress in Hormone Research, vol. 39, pp. 559-598, 1983.

[15] O. Tan, T. Ornek, Y. Seval, L. Sati, and A. Arici, "Tenascin is highly expressed in endometriosis and its expression is upregulated by estrogen," Fertility and Sterility, vol. 89, no. 5, pp. 1082-1089, 2008.

[16] R. Nishiura, N. Noda, H. Minoura et al., "Expression of matrix metalloproteinase-3 in mouse endometrial stromal cells during early pregnancy: regulation by interleukin- $1 \alpha$ and tenascin-C," Gynecological Endocrinology, vol. 21, no. 2, pp. 111118, 2005.

[17] M. Slater, C. R. Murphy, and J. A. Barden, “Tenascin, Ecadherin and P2X calcium channel receptor expression is increased during rat blastocyst implantation," Histochemical Journal, vol. 34, no. 1-2, pp. 13-19, 2002.

[18] N. Noda, H. Minoura, R. Nishiura et al., "Expression of Tenascin- $\mathrm{C}$ in stromal cells of the murine uterus during early pregnancy: induction by interleukin- $1 \alpha$, prostaglandin E2, and prostaglandin $\mathrm{F}(2 \alpha)$," Biology of Reproduction, vol. 63, no. 6, pp. 1713-1720, 2000.

[19] M. Taguchi, T. Kubota, and T. Aso, "Immunohistochemical localization of tenascin and ki-67 nuclear antigen in human endometrium throughout the normal menstrual cycle," Journal of Medical and Dental Sciences, vol. 46, no. 1, pp. 7-12, 1999.

[20] M. Sedele, S. Karaveli, H. E. Peştereli et al., "Tenascin expression in normal, hyperplastic, and neoplastic endometrium," International Journal of Gynecological Pathology, vol. 21, no. 2, pp. 161-166, 2002. 


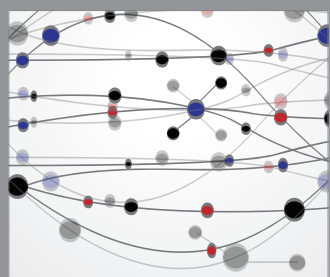

The Scientific World Journal
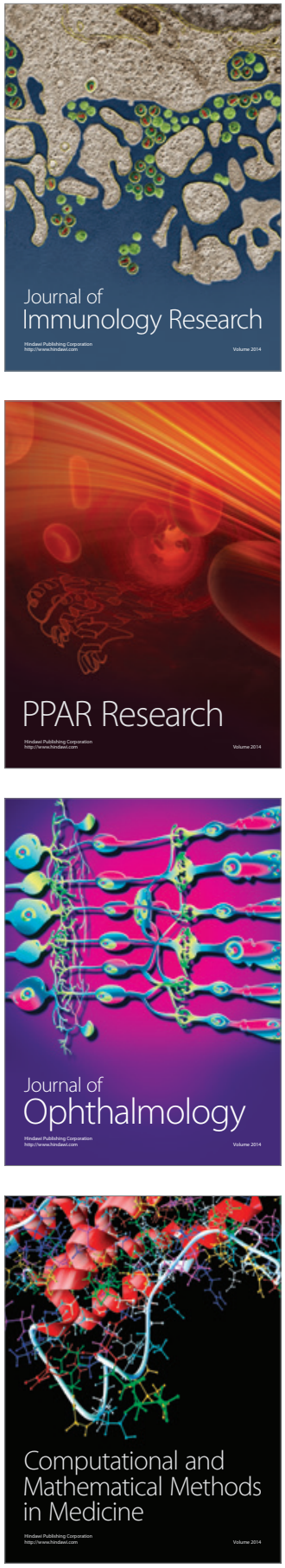

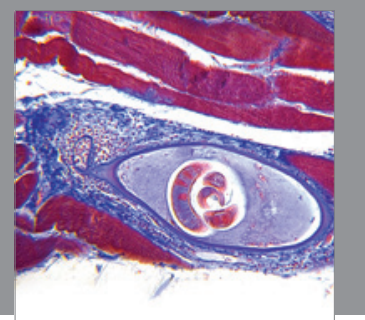

Gastroenterology

Research and Practice
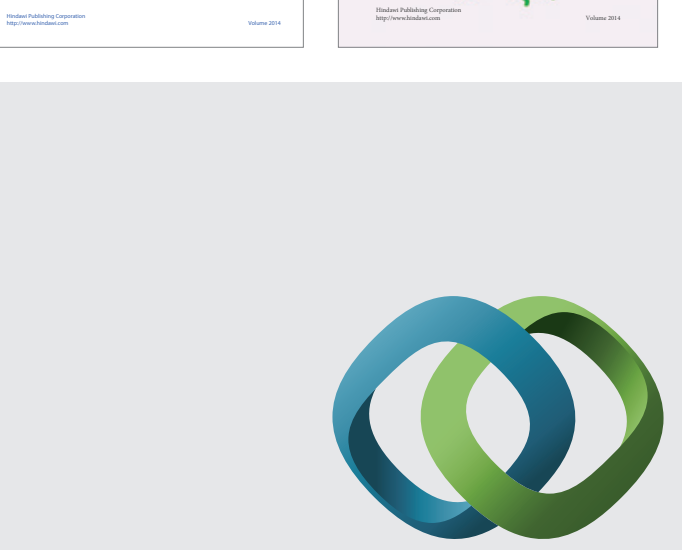

\section{Hindawi}

Submit your manuscripts at

http://www.hindawi.com
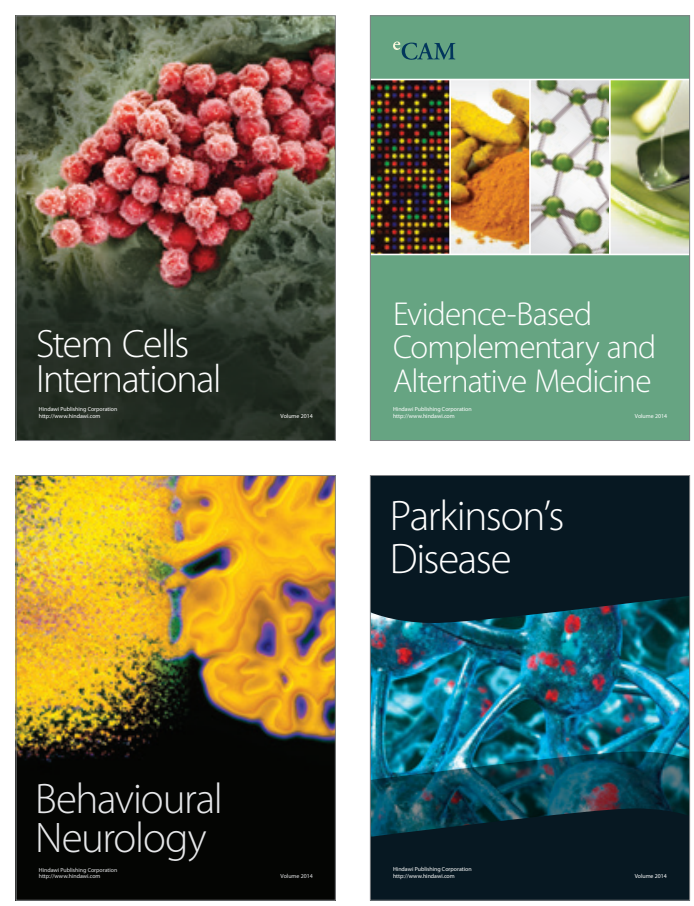

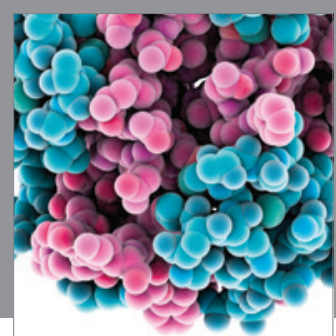

Journal of
Diabetes Research

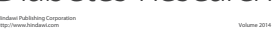

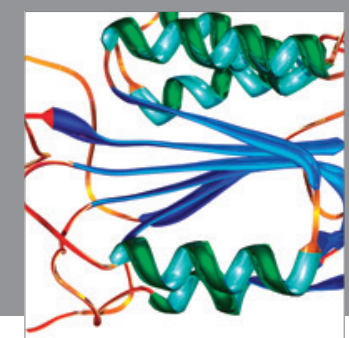

Disease Markers
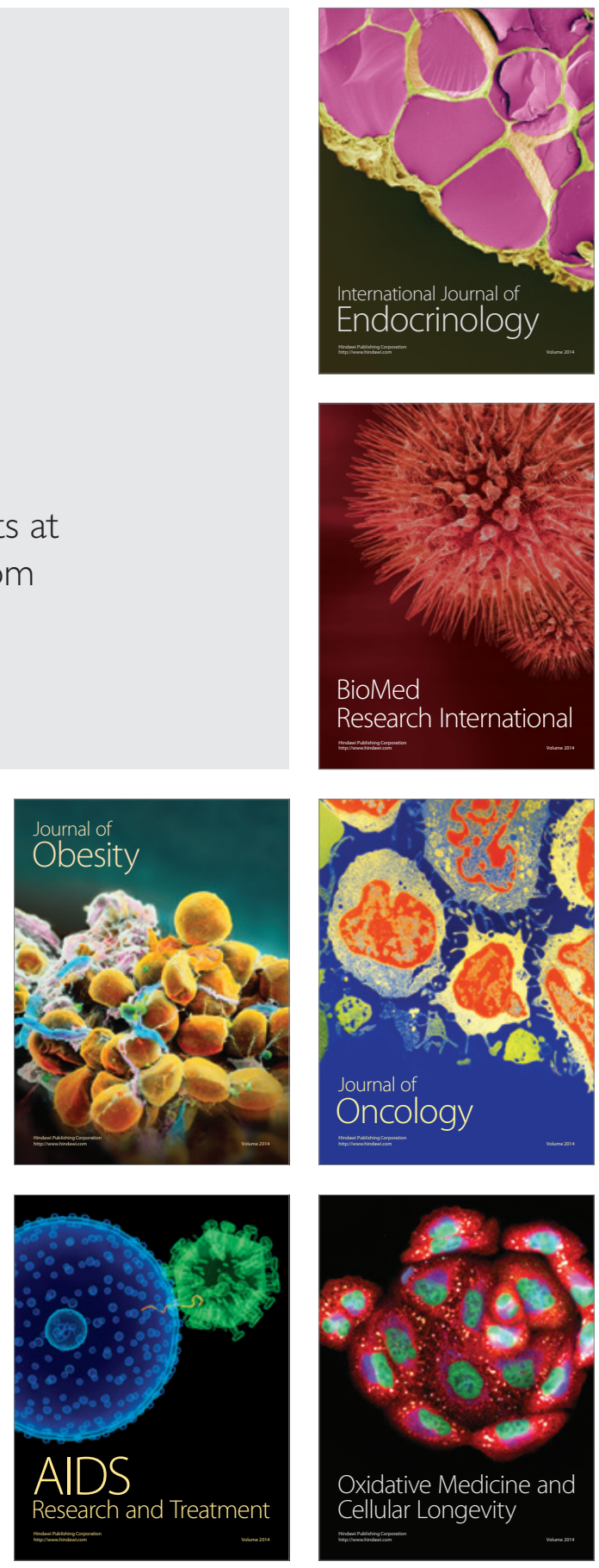